\title{
KOLABORASI PENGEMBANGAN KAWASAN GEOPARK DALAM MEWUJUDKAN DESTINASI PARIWISATA BERKELAS DUNIA DI PROVINSI JAWA BARAT
}

\author{
Shafira Mediana Putri \\ Program Studi Magister Kebijakan Publik, Fakultas Ilmu Sosial dan Ilmu Politik \\ Universitas Padjadjaran \\ firamediana.21@gmail.com
}

\begin{abstract}
ABSTRAK
Penelitian ini bertujuan untuk mendeskripsikan tentang kolaborasi di antara para pemangku kepentingan dalam rangka pengembangan Pariwisata Geopark Ciletuh dalam mewujudkan destinasi pariwisata berkelas dunia Penelitian ini dilatarbelakangi oleh UNESCO yang menetapkan Kawasan Geopark Ciletuh sebagai Global Geopark dimana hal tersebut dapat menjadi magnet menarik wisatawan dari berbagai belahan dunia untuk berkunjung, oleh karena itu pemerintah daerah melakukan pengembangan wisata daerah ciletuh dapat menjadi destinasi wisata berkelas dunia. Metode penulisan jurnal ini melalui studi literatur melalui berbagai informasi dalam dokumen, buku, jurnalilmiah, koran, majalah, serta sumber informasi dari laman situs/website melalui internet. Hasil penelitian ini menunjukkan bahwa (1) pemangku kepentingan dalam pengembangan wisata geopark Ciletuh yang berperan adalah departemen pariwisata dan budaya, pemerintah provinsi Jawa Barat dan Pemerintah Kabupaten Sukabumi sebagai pembuat kebijakan dan koordinator (2) kolaborasi antara pemangku kepentingan dalam upaya mengembangkan objek wisata geopark Ciletuh yang menunjukkan arah dalam kelembagaan yang dirancang di mana peran pemangku kepentingan tidak saling mengganggu. Dimensi proses kolaborasi ditemukan hasil dalam bentuk rencana kerja target untuk pengembangan geopark Ciletuh.
\end{abstract}

Kata kunci; Kolaborasi, Kebijakan, Pengembangan Pariwisata, Geopark

\begin{abstract}
The present research aims to describe collaboration among stakeholders in the context of developing Ciletuh Geopark Tourism in realizing classy tourism destinations. This research was motivated by UNESCO who developed the Ciletuh Geopark Region as a Global Geopark, this magnet can be used. Visiting, therefore the local government to develop ciletuh regional tourism can become a world-class tourist destination. The method of selecting this journal is through literature studies through various information in documents, books, scientific journals, newspapers, magazines, and sources of information from the website / website through the internet. The results of this study indicate the fact that (1) stakeholders in the development of Ciletuh geopark tourism related are the department of sports and culture, the provincial government of West Java and Sukabumi Regency Government as policy makers and coordinators (2) participation of researchers related to involvement in the construction of the Ciletuh geopark tourist resort which shows directions in institutions designed where the desired role is not interdependent.The dimensions of the collaboration process found results in the form of a target work plan for the development of the Ciletuh geopark.
\end{abstract}

Key words : Collaboration, Policy, Tourism Development, Geopark

\section{LATAR BELAKANG}

Negara Kesatuan Republik Indonesia memiliki kekayaan dan keragaman berupa letak geografis strategis, keanekaragaman

bahasa dan suku bangsa, keadaan alam, geologi, flora, dan fauna, peninggalan purbakala, serta peninggalan sejarah, seni, dan budaya yang merupakan sumber daya dan modal dalam sektor kepariwisataan untuk meningkatkan kemakmuran dan kesejahteraan bangsa Indonesia sebagaimana terkandung dalam Pancasila dan dicita-citakan dalam Pembukaan Undang-Undang Dasar Negara Republik Indonesia Tahun 1945.

Undang-Undang RI Nomor 10 Tahun 2009 tentang Kepariwisataan mengamanatkan fungsi pariwisata untuk memenuhi kebutuhan jasmani, rohani, dan intelektual setiap wisatawan dengan rekreasi dan 


\section{Kolaborasi Pengembangan Kawasan Geopark Dalam Mewujudkan Destinasi Pariwisata Berkelas Dunia Di Provinsi Jawa Barat (Shafira Mediana Putri )}

perjalanan serta meningkatkan pendapatan negara untuk mewujudkan kesejahteraan rakyat. Pembangunan kepariwisataan diarahkan untuk mewujudkan tujuan kepariwisataan, yaitu: (a). meningkatkan pertumbuhan ekonomi; (b). meningkatkan kesejahteraan rakyat; (c). menghapus kemiskinan; (d). mengatasi pengangguran; (e). melestariakan alam, lingkungan, dan sumber daya; (f) memajukan kebudayaan; (g) mengangkat citra bangsa; (h) memupuk rasa cinta tanah air; (i) memperkokoh jati diri dan kesatuan bangsa; dan (j) mempererat persahabatan antar bangsa.

Pembangunan kepariwisataan di Provinsi Jawa Barat diwujudkan melalui pelaksanaan rencana pembangunan kepariwisataan dengan memperhatikan keanekaragaman, keunikan, dan kekhasan budaya dan alam, serta kebutuhan manusia untuk berwisata di kawasan strategis pariwisata. Selain itu, aspek yang diatur dalam pembangunan kepariwisataan di Provinsi Jawa Barat meliputi industri pariwisata, destinasi pariwisata, pemasaran pariwisata, dan kelembagaan kepariwisataan.

Membangun destinasi pariwisata berkelas dunia adalah destinasi yang memenuhi standar internasional Global Sustainable Tourism Council (GSTC) dengan mempertimbangkan aspek lingkungan, sosial/masyarakat, dan ekonomi.

Destinasi pariwisata tersebut, memiliki magnet menarik wisatawan dari berbagai belahan dunia untuk berkunjung; yang menyuguhkan keragaman jenis wisata mulai dari alam yang terawat, aktraksi budaya yang khas, kuliner, dan yang tidak kalah penting adanya kemudahan fasilitas dan aksesbilitas ke destinasi tesebut, sehingga tingkat komplain wisatawan rendah.

Dalam rangka mengembangkan destinasi pariwisata berkelas dunia yang mengintegrasikan kekayaan potensi pariwisata daerah yang khas dan berdaya saing global, Pemerintah Provinsi Jawa Barat terus melakukan upaya yang holistik dan berkelanjutan. Salah satu upaya dilakukan diantaranya mengembangkan konsepsi dan potensi Geopark, yakni sebuah konsep manajemen pengembangan berkelanjutan yang menyerasikan keragaman geologi (geodiversity), hayati (biodiversity), dan budaya (cultural diversity) melalui prinsip konservasi dan Rencana Tata Ruang Wilayah yang sudah ada.

Geopark adalah wilayah geografis yang memiliki situs warisan geologi terkemuka dan bagian dari konsep holistik perlindungan, pendidikan, dan pembangunan yang berkelanjutan. Geopark tidak hanya mencakup situs geologi, tetapi memiliki batas geografis yang jelas serta sinergitas antara keragaman geologi, hayati, dan budaya yang ada di dalam kawasan tersebut. Masyarakat yang tinggal di dalam lawasan berperan serta untuk melindungi dan meningkatkan fungsi warisan alam. Status geopark yang sudah diakui secara Internasional adalah Ciletuh Palabuhanratu dengan nama Ciletuh Palabuhanratu Unesco Global Geopark (CP UGG), sedangkan 4 zona kawasan geopark lainnya masuk dalam kategori usulan (aspiring) ke tingkat nasional.

Pada awalnya Geopark Ciletuh Palabuhanratu ditetapkan sebagai geopark nasional pada tanggal 22 Desember 2015 dengan kawasannya meliputi Kecamatan Ciemas di bagian utara dan Kecamatan Ciracap di bagian selatan. Dalam rangka "Advisory Mission”, kawasan geopark Ciletuh Palabuhanratu disarankan untuk memperluas kawasan ke arah utara dan barat menjadi 8 (delapan) kecamatan, apabila statusnya menjadi geopark nasional dan global.

Untuk mewujudkan potensi geopark secara umum di Jawa Barat, dan khususnya pada pilot project Geopark Ciletuh Palabuhanratu sebagai destinasi pariwisata berkelas dunia (world class tourism), tentunya perlu dukungan infrastruktur, fasilitas, regulasi, kebijakan pemerintah dan program pemberdayaan masyarakat. Geopark memiliki semboyan: "Memuliakan Bumi, Mensejahterakan Masyarakat ("Celebrating Earth Heritage, Sustaining Local Communities”). Pembangunan dan penumbuhan perekonomian berkelanjutan pada kawasan geopark dikembangkan melalui paket pariwisata seperti: geowisata, wisata bahari, wisata petualangan, wisata budaya, wisata belanja dan wisata kuliner. Sejalan dengan ditetapkannya Ciletuh Palabuhanratu menjadi status Unesco Global Geopark (Geopark Internasional) tentu perlu percepatan terhadap komitmen seluruh stakeholder dan target-target capaian yang sudah ditetapkan.

Dalam rangka pengembangan Geopark di provinsi Jawa Barat, diperlukan tata kelola geopark yang handal dan profesional. Pembagian peran pemerintah pusat, pemerintah provinsi, dan pemerintah daerah kabupaten serta masyarakat harus tertuang dengan jelas dalam kebijkan daerah. Secara khusus bahwa tata kelola kawasan geopark di Provinsi Jawa Barat menunjukkan kondisi yang belum sinergis dan belum terpadu diantara stakeholder yang ada, baik dari sisi kebijakan maupun operasional kegiatannya. Keberadaan lembaga pengelola yang telah dibentuk di masing-masing kawasan geopark di Jawa Barat belum mampu melaksanakan pengelolaan kawasan geopark handal, profesional dan sinergis.

Berdasarkan pertimbangan tersebut, maka dalam proyek perubahan ini perlu adanya upaya yang 
signifikan dan terukur dengan membuat langkah kebijakan yang inovatif, yakni melakukan Kolaborasi Pengembangan Kawasan Geopark Dalam Mewujudkan Destinasi Pariwisata BerkelasDunia (World Class Tourism) Di Provinsi Jawa Barat.

\section{KAJIAN PUSTAKA}

\section{Konsep Geopark}

Berdasarkan Global Geopark Network (GGN) dan European Geopark Network (EGN) bahwa definisi Geopark adalah wilayah dengan batas yang didefinisikan dengan baik yang terdiri dari wilayah luas yang memungkinkan pembangunan lokal berkelanjutan, baik pada aspek sosial, ekonomi, budaya, dan lingkungan. Selanjutnya, menurut UNESCO (2006), Geopark adalah wilayah yang dapat didefinisikan sebagai kawasan lindung berskala nasional yang mengandung sejumlah situs warisan geologi penting yang memiliki daya tarik keindahan dan kelangkaan tertentu yang dapat dikembangkan sebagai bagian dari konsep integrasi konservasi, pendidikan, dan pengembangan ekonomi lokal.

Berdasarkan beberapa definisi Geopark tersebut, secara singkat Geopark ini merupakan bentuk pemanfaatan ruang kawasan lindung yang juga merupakan sebuah kesempatan untuk mencapai pembangunan berkelanjutan. Didalam mewujudkan aspirasi Geopark, terdapat tiga pendekatan yang berbeda, yaitu, pelestarian / konservasi, pendidikan, dan pembangunan berkelanjutan (Newsome et al., 2012; Farsani et al., 2011).

Menurut Setyadi (2012) secara singkat Geopark ini merupakan bentuk pemanfaatan ruang kawasan lindung yang juga merupakan sebuah kesempatan untuk mencapai pembangunan berkelanjutan. Sedangkan menurut Darsiharjo dkk. (2016) Geopark adalah taman bumi yang termasuk dalam kawasan konservasi, yang memiliki unsur geodiversity (keragaman geologi), biodiversity (keragaman hayati, dan cultural diversity (keragaman budaya)) yang di dalamnya memiliki aspek dalam bidang pendidikan sebagai pengetahuan di bidang ilmu kebumian pada keunikan dan keragaman warisan bumi dan aspek ekonomi dari peran masyarakat dalam pengelolaan kawasan sebagai geowisata.

\section{Konsep Pengembangan Pariwisata}

Menurut Gamal Suwantoro (2004:3) Pariwisata adalah suatu proses kepergian sementara dari seseorang atau lebih menuju tempat lain di luar tempat tinggalnya. Dorongan kepergiannya adalah karena berbagai kepentingan, baik karena kepentingan ekonomi, sosial, kebudayaan, politik, agama, kesehatan maupun kepentingan lain seperti karena sekedar ingin tahu, menambah pengalaman ataupun untuk belajar.

Menurut Cox,1985 dalam Downling dan Fennel,2003,2 (dalam I Gde Pitana dan I Ketut Surya Diarta, 2009:81), pengelolaan manajemen pariwisata harus memperhatikan prinsip-prinsip berikut:

1 Pembangunan dan pengembangan pariwisata haruslah didasarkan pada kearifan lokal (local wisdom) dan special local sense yang merefleksikan keunikan peninggalan budaya dan keunikan lingkungan.

2 Preservasi, proteksi, dan peningkatan kualitas sumber daya yang menjadi basis pengembangan kawasan pariwisata.

3 Pengembangan atraksi wisata tambahan yang mengakar pada khasanah budaya lokal

4 Pelayanan kepada wisatawan yang berbasis keunikan budaya dan lingkungan lokal.

5 Memberikan dukungan dan legitimasi pada pembangunan dan pengembangan pariwisata jika terbukti memberikan manfaat positif, tetapi sebaliknya mengendalikan dan/atau mengehentikan aktivitas pariwisata tersebut jika melampaui ambang batas (carrying capacity) lingkungan alam atau akseptabilitas sosial walaupun disisi lain mampu meningkatkan pendapatan masyarakat.

\section{Konsep KebijakanPublik}

Dalam Kamus Besar Bahasa Indonesia, kebijakan diartikan sebagai rangkaian konsep dan asas yang menjadi garis besar dan dasar rencana dalam pelaksanaan suatu pekerjaan, kepemimpinan, dan cara bertindak (tentang pemerintahan, organisasi, dan sebagainya); pernyataan cita-cita, tujuan, prinsip dan garis pedoman untuk manajemen dalam usaha mencapaisasaran.

Mengutip definisi kebijakan yang diambil dari pendapat Federick dalam buku Agustino menyatakan bahwa kebijakan sebagai serangkaian tindakan atau kegiatan yang diusulkan seseorang, kelompok atau pemerintah dalam suatu lingkungan tertentu dimana terdapat hambatan-hambatan (kesulitan-kesulitan) dan kesempatan- kesempatan terhadap pelaksanaan usulan kebijaksanaan tersebut dalamrangka mencapai tujuan tertentu. Pendapat ini juga menunjukan bahwa ide kebijakan melibatkan perilaku yang memiliki maksud dan tujuan merupakan bagian yang penting dari definisi kebijakan, karena bagaimanapun kebijakan harus menunjukan apa yang sesungguhnya dikerjakan 
daripada apa yang diusulkan dalam beberapa kegiatan pada suatu masalah (Leo Agustino, 2008)

\section{METODE}

Metode yang digunakan untuk penulisan ini adalah Studipustaka. StudiPustaka dilakukan karena banyaknya informasi dan data mengenai Kebijakan Pengembangan Pariwisata Geopark. Hal ini dapat ditelusuri melalui berbagai informasi dalam buku, jurnal ilmiah, koran, majalah, serta sumber informasi dari laman situs/website melalui internet. Studi pustaka menjadi penting dalam menganalisa Kebijakan Pengembangan Pariwisata Geopark.

\section{PEMBAHASAN}

\section{Stakeholder dalam Pengembangan Pariwisata Geopark Ciletuh}

Sebagai upaya pariwisata geopark Ciletuh tentu harus melalui rancangan- rancangan atau aturan yang sudah ditetapkan dalam peraturan pengembangan pariwisata geopark dan juga penentuan aktor-aktor yang berperan dalam pengembangan pariwisata geopark ciletuh. Pengembangan pariwisata geopark Ciletuh yang djalankan oleh beberapa stakeholder dalam hal ini mereka yang saling terkait dalam pengenalan dan pengembangan wisata geopark. Dengan terkenalnya geopark ciletuh tentu terdapat banyak keuntungan yang didapatkan oleh baik pemerintah atau masyarakat sekitar.

Identifikasi aktor-aktor yang terkait dalam pengembangan wisata geopark Ciletuh ini juga perlu untuk diperhatikan karena ketika telah mengetahui setiap aktor-aktor atau stakeholder yang terkait maka selanjutnya akan mengetahui bagaimana kolaborasi antar setiap aktornya. Dalam pengembangan pariwisata Geopark Ciletuh terdapat Stakeholder yang berpengaruh berdasarkan kuadran dengan kelompok Promoters, Latents, Defenders dan Apathetics yaitu sebagai berikut :

- Promoters :

$\begin{array}{ll}1 & \text { Gubernur } \\ 2 & \text { Wakil Gubernur } \\ 3 & \text { Ketua DPRD Provinsi Jabar } \\ 4 & \text { Kepala Deputi PDIP Kementerian } \\ & \begin{array}{l}\text { Pariwisata RI } \\ 5\end{array} \\ & \text { Kepala Badan Geologi Kementerian } \\ & \text { ESDM RI } \\ 6 & \text { Badan Promosi Pariwisata Daerah } \\ 7 & \text { Bupati Sukabumi } \\ 8 & \text { Bupati Pangandaran } \\ 9 & \text { Bupati Bandung Barat }\end{array}$

1 Gubernur

3 Ketua DPRD Provinsi Jabar

Pariwisata RI ESDM RI

6 Badan Promosi Pariwisata Daerah

7 Bupati Sukabumi

9 Bupati Bandung Barat

\section{Bupati Bogor}

- Latents :

1. Kepala Biro Pemerintahan dan Kerjasama

2. Kepala Biro Hukum dan HAM

3. Kepala Biro

4. Akademisi Perguruan Tinggi

5. BUMN/BUMD

6. Media Massa/Elektronik

7. Tokoh Masyarakat Jawa Barat

- Defenders :

1. Bappeda Provinsi Jawa Barat

2. Kepala BPKAD

3. Kepala Dinas Pariwisata dan Kebudayaan Prov.

4. Kepala Dinas Lingkungan Hidup Prov.

5. Kepala Dinas Kehutanan Prov.

6. Kepala Dinas ESDM Prov.

7. Kepala Dinas Bina Marga dan Penataan Ruang Prov.

8. Kepala Dinas Koperasi dan UKM Prov.

9. Kepala Dinas Perhubungan Prov.

10. Dinas Pariwisata Kabupaten Pangandaran

11. Dinas Pariwisata Kabupaten Sukabumi

12. Dinas Pariwisata Kabupaten Bandung Barat

13. Dinas Pariwisata Kabupaten Bogor

14. Kepala BBKSDA Jabar

15. Ketua PHRI Jawa Barat

16. Pengusaha Bidang Pariwisata 
Gambar.4.1 Identifikasi Stakeholder Pengembangan Pariwisata Geopark Ciletuh

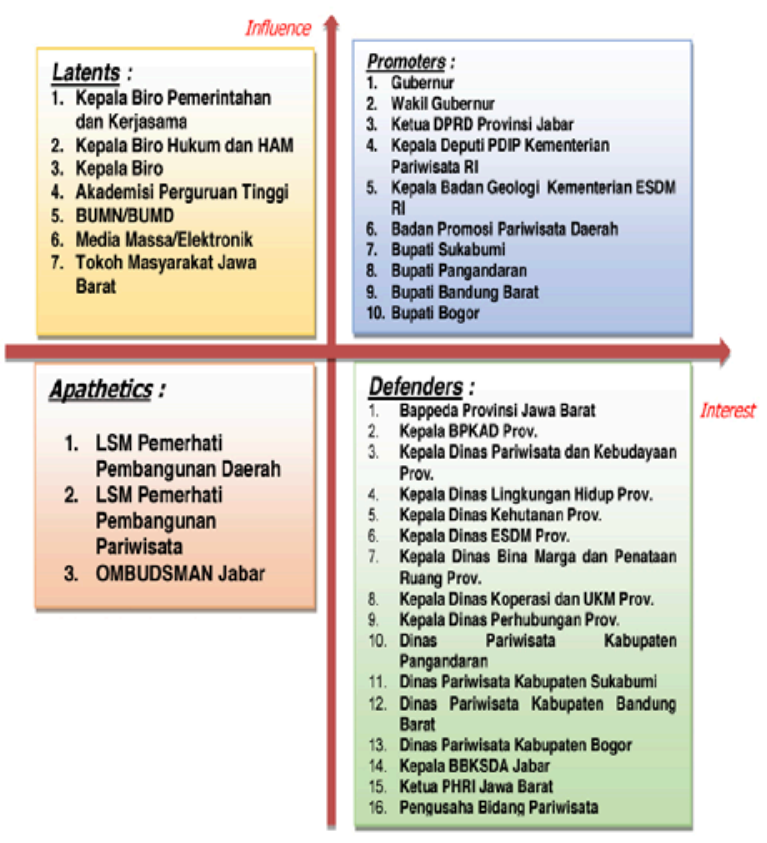

(Sumber : Dok. Dinas Pariwisata Kab. Sukabumi, 2019)

Proses Kolaborasi antar Stakeholder dalam Pengembangan Pariwisata Geopark Ciletuh

Dapat dianalisis bahwa pada bentuk kolaborasi yang ada dalam pengembangan pariwisata pariwisata geopark Ciletuh menunjukan arah pada Institutional Designd dimana peran para stakeholder satu dengan yang lain tidak saling mengintervensi serta dimana keberhasilan dimensi hasil sementara dalam proses kolaborasi terdapat tujuan yang tepat serta terbentuknya target rencana kerja yang dapat mendekatkan pada tujuan yang ingin dicapai dalam mengenalkan destinasi wisata religi sunan giri pada pihak-pihak luar. Bentuk kolaborasi institusional design dapat dilihat dari bebeerapa kesimpulan dari indikator proses kolaborasi sebagai berikut :

- Tahap Pembentukan Tim Efektif dan Penerimaan Sertifikat Keanggotaan Global Geopark Network

Tahapan pertama dari aktualisasi proyek perubahan adalah pembentukan tim efektif proyek perubahan yang dilaksanakan rapatnya pada hari Senin tanggal 17 September 2018. Sebelum pembentukan tim efektif, project leader mendapat tugas untuk menerima Sertifikat Keanggotaan Global Geopark Network ke Italia dari tanggal 10
September s.d 14 September 2018. Pemberian Sertifikat ini kepada Pemerintah Kabupaten Sukabumi dengan waktu yang bersamaan dengan tahapan pembentukan tim efektif. Penetapan tim efektif proyek perubahan ini langsung dilakukan oleh Gubernur Jawa Barat dengan menerbitkan Surat Keputusan tertanggal 17 September 2018.

- Tahap Pelaksanaan Koordinasi, Konsultasi, Audensi dan Focus Group Discussion (FGD)

Tahapan kedua dari aktualisasi proyek perubahan adalah Pelaksanaan Koordinasi, Konsultasi, Audensi dan Focus Group Discussion (FGD). Pelaksanan koordinasi, konsultasi dan audensi kepada stakeholder eksternal dimulai tanggal 18 s.d. 21 September 2018. Selanjutnya dilaksankan FGD pada tanggal 24 September 2018 di Gedung Sate Bandung dalam rangka persiapan penyusunan Rapergub dan naskah MoU serta Perjanjian Kerjasama dan Kesepakatan bersama dalam rangka pengembangan kawasan geopark di Jawa Barat. Hal ini perlu dilakukan dalam rangka membahas substansi Rapergub dan naskah MoU serta Perjanjian Kerjasama dan Kesepakatan bersama.

- Tahap Penyusunan Peraturan Gubernur Jawa Barat tentang Pengembangan Kawasan Geopark di Daerah Provinsi Jawa Barat

Tahapan ketiga dari aktualisasi proyek perubahan adalah penyusunan Peraturan Gubernur Jawa Barat. Dalam tahapan ini terdapat empat (4) kegiatan, yakni penyusunan rancangan Peraturan Gubernur Jawa Barat dari tanggal 1 s.d. 5 Oktober 2018, Pelaksanaan Legal Drafting Rapergub tanggal 8 s.d. 10 Oktober 2018, Pelakaanaan Harmonisasi Pergub tanggal 22 s.d. 25 Oktober 2018 dan Pengesahan Pergub tanggal 26 Oktober 2018. Project Leader dalam tahapan ini banyak dibantu oleh tim efektif, mengingat selain melakukan penyusunan Pergub ini masih dilakukan koordinasi dan konsultasi kepada stakeholder eksternal. 
- Tahap Sosialisasi Peraturan Gubernur Jawa Barat tentang Pengembangan Kawasan Geopark di Daerah Provinsi Jawa Barat

Tahapan keempat dari aktualisasi proyek perubahan adalah pelaksanaan sosialisasi Peraturan Gubernur Jawa Barat tentang Pengembangan Kawasan Geopark di Daerah Provinsi Jawa Barat. Sosialisasi ini dilaksanakan pada tanggal 6 November 2018.

- Tahap Sosialisasi Peraturan Gubernur Jawa Barat tentang Pengembangan Kawasan Geopark di Daerah Provinsi Jawa Barat

Tahapan keempat dari aktualisasi proyek perubahan adalah pelaksanaan sosialisasi Peraturan Gubernur Jawa Barat tentang Pengembangan Kawasan Geopark di Daerah Provinsi Jawa Barat. Sosialisasi ini dilaksanakan pada tanggal 6 November 2018.

- Tahap Pelaksanaan Jejaring Kerjasama Antara Ciletuh Palabuhanratu Unesco Global Geopark Dengan Gunung Sewu Unesco Global Geopark

Tahapan kelima dari aktualisasi proyek perubahan adalah melaksanakan kesepakatan bersama Antara Badan Pengelola Ciletuh Palabuhanratu Unesco Global Geopark dengan General Manager Gunung Sewu Unesco Global Geopark. Kegiatan ini merupakan langkah adopsi dan adaptasi ke Gunung Sewu Unesco Global Geopark karena lebih dulu mendapat sertifikat Unesco Global Geopark. Kegiatan ini dilaksanakan tanggal 7 s,.d 10 November 2018.

- Tahap Implementasi Kolaborasi Pengembangan Kawasan Geopark pada Lokasi Pilot Project di Ciletuh Palabuhanratu Unesco Global Geopark

Tahapan ketujuh dari aktualisasi proyek perubahan adalah impelemntasi kolaborasi pengembangan kawasan geopark dengan lokasi pilot poject di Ciletuh Palabuhanratu Unesco Global Geopark. Dalam implementasi kolaborasi ini dilaksanakan CP-UGG Festival, penandatanganan Perjanjian Kerjasama Antara Bupati Sukabumi dengan LIPI, UPI dan Balai Pengelolaaan Daerah Aliran Sungai dan Hutan Lindung Citarum Ciliwung. Selanjutnya dilaksanakan diseminasi pemanfaatan IPTEK dan Bimbingan Teknis kemasan Produk Kreatif dalam rangka memberdayakan ekonomi lokal. Kegiatan implementasi kolaborasi ini dilaksanakan mulai tanggal 12 sd.d. 21 Novermber 2018.

Dari tahapan tersebut menghasilkan beberapa capaian dalam rangka upaya pengembangan pariwisata Geopark Ciletuhyaitu :

1 Terbitnya Peraturan Gubernur Jawa Barat Nomor 72 tahun 2018 tentang Pengembangan Kawasan Geopark di Daerah Provinsi Jawa Barat tertanggal 26 Oktober 2018.

2 Terlaksana Sosialisasi Peraturan Gubernur Jawa Barat Nomor 72 tahun 2018 tentang Pengembangan Kawasan Geopark di Daerah Provinsi Jawa Barat. Sosialisasi ini dilaksankan pada tanggal 6 November 2018.

3 Terjalin kerjasama antara Badan Pengelola Ciletuh Palabuhanratu Unesco Global Geopark dengan General Manager Gunung Sewu Unesco Global Geopark, Kerjsama ini dalam rangka adopsi dan adaptasi tata cara pengelolaan Gunung Sewu Global Geopark yang terlebih dahulu mendapat sertifikat Unesco Global Geopark.

4 Terjalin impelementasi kolaborasi pengembangan kawasan geopark dengan lokasi pilot project di Ciletuh Palabuhanratu Unesco Global Geopark. Dalam implementasi kolaborasi ini dilaksanakan CP-UGG Festival, penandatanganan Perjanjian Kerjasama Antara Bupati Sukabumi dengan LIPI, UPI dan Balai Pengelolaaan Daerah Aliran Sungai dan Hutan Lindung Citarum Ciliwung. Selanjutnya dilaksanakan diseminasi pemanfaatan IPTEK dan Bimbingan Teknis kemasan Produk Kreatif dalam rangka memberdayakan ekonomi lokal.

\section{PENUTUP}

Geopark Ciletuh ditetapkan oleh UNESCO sebagai Interntional Geopark, hal tersebut dapat menjadi magnet menarik wisatawan dari berbagai belahan dunia untuk berkunjung, oleh karena itu pemerintah daerah melakukan pengembangan wisata daerah ciletuh dapat menjadi destinasi wisata berkelas dunia. Salah satunya kolaborasi stakeholder dalam pengembangan pariwisata Geopark Ciletuh, kolaborasi antara stakeholder dalam upaya mengembangkan objek wisata geopark Ciletuh yang menunjukkan arah dalam kelembagaan yang dirancang di mana peran pemangku kepentingan tidak saling mengganggu. Dimensi proses kolaborasi ditemukan hasil 4 capaian dan rencana kerja target untuk pengembangan geopark Ciletuh. 


\section{DAFTAR PUSTAKA}

Buku:

Agustino, Leo. 2008. Dasar-Dasar

KebijakanPublikAlfabeta : Bandung

.Dun, William N. 2000.PengantarAnalisis

KebijakanPublik. GadjahMadda University Press : Yogyakarta.

Morris, John C and Katrina Miller -

Stevens.2016. Advancing

Collaboration Theory: Models,

Typologies and Evidence. London :

Routledge Taylor Francis Group

\section{Jurnal :}

Darsiharjo, Upi, Ilham. 2016.Pengembangan

Geopark Ciletuh Berbasis Partisipasi Masyarakat Sebagai Kawasan Geowisata Di Kabupaten Sukabumi. Universitas Pendidikan Indonesia :Jurnal Manajemen Resort \& Leisure

Khairil\&Yuhanis. 2010. Tourism Policy

Development: A Malaysian Experience Tourism Policy Development: A Malaysian Experience. Universiti Putra Malaysia :Reasearch Gate

Mastura Jaafar, Aleff Omar Shah Nordin,

Shardy Abdullah \&Azizan Marzuki. 2014. Geopark Ecotourism Product Development: A Study on Tourist Differences. Canadian Center of Science and Education

Pedrana, Margherita. 2013. Local Economic

Development Policies And Tourism. An Approach To Sustainability And Culture . European University of Rome : Regional Science Inquiry Journal

Tawonezvi Charleen, Mirimi Kumbirai,

Kabote Forbes. 2014. Collaboration And Stakeholder Involvement For Tourism Development In Zimbabwe. International Journal Of Advanced Research In Management And Social Sciences

\section{Dokumen :}

Laporan Dinas Pariwisata Kabupaten

Sukabumi Aktualisasi

Pengembangan Geopark Ciletuh

Website :

"Geopark Ciletuh-Palabuhanratu Ditetapkan sebagai Unesco Global Geopark - Kompas.com”

(https://regional.kompas.com/read/2018/04/16/133013 41/geopark-ciletuh-palabuhanratuditetapkan-sebagai-unesco-global-geopark)

"Pengelolaan Geopark di Indonesia Masih Terkotakkotak"

(https://ekonomi.bisnis.com/read/20160925/12/58683 3/pengelolaan-geopark-di-indonesia-masihterkotak-kotak)

"Musrenbang Jabar, Sukabumi Akan Lakukan Kolaborasi | Portal Resmi Pemda Kabupaten Sukabumi”

(Https://Sukabumikab.Go.Id/Portal/BeritaDaerah/1967/Musrenbang-Jabar-SukabumiAkan-Lakukan-Kolaborasi.Html)

"Pengembangan Geopark Ciletuh - Pelabuhan Ratu, Pemkab Sukabumi Akan Revisi RTRWTribunJabar"

(Https://Jabar.Tribunnews.Com/2018/11/08/Pengemba ngan-Geopark-Ciletuh-Pelabuhan-RatuPemkab-Sukabumi-Akan-Revisi-Rtrw)

"Gubernur Jabar Apresiasi Karya Inovatif Sekda Sukabumi Dalam Mengembangkan Kawasan Geopark Ciletuh Menuju Pariwisata Berkelas Dunia - Berantas Online”

(Https://Www.Berantasonline.Com/Gubernur-JabarApresiasi-Karya-Inovatif-Sekda-SukabumiDalam-Mengembangkan-Kawasan-GeoparkCiletuh-Menuiu-Pariwisata-Berkelas-Dunia/)

"Luhut Binsar Panjaitan: Sinkronisasi Aturan Perlu Dilakukan Untuk Pengembangan Geopark. Ciletuh Palabuhanratu"

(Http://Ciletuhpalabuhanratugeopark.Org/LuhutBinsar-Panjaitan-Sinkronisasi-Aturan-PerluDilakukan-Untuk-Pengembangan-Geopark/) 